\title{
SPECIFICATION OF ENVIRONMENTAL CONSULTING SERVICES IN POLAND AND WESTERN POMERANIA
}

\author{
ELŻBIETA DUSZA-ZWOLIŃSKA, ${ }^{1}$ MICHAŁ KUPIEC, ${ }^{2}$ ANNA KIEPAS-KOKOT ${ }^{3}$ \\ ${ }^{1}$ West Pomeranian Technological University in Szczecin, Faculty of Environmental Development and Agriculture, POLAND \\ e-mail: edusza@zut.edu.pl \\ ${ }^{2}$ University of Szczecin, Faculty of Earth Sciences, POLAND \\ e-mail: michal.kupiec@usz.edu.pl \\ ${ }^{3}$ West Pomeranian Technological University in Szczecin, Faculty of Environmental Development and Agriculture, POLAND \\ e-mail: annakiepaskokot@o2.pl
}

\begin{tabular}{l|l} 
RECEIVED & 10 December 2018 \\
ACCEPTED & 28 December 2018
\end{tabular}

JEL

CLASSIFICATION

Q28, Q51

KEYWORDS

ABSTRACT environmental management, environmental consulting services, environmental impact assessment

The work describes services within the scope of environmental consulting and management in Poland, as a result of developing of legal system of environmental proteection. Legal sources for the needs of such services for entrepreneurs were defined and compared to the market offers of companies dealing with environmental services. The spatial distribution and size of companies in the West Pomeranian Voivodeship and in the country scale are presented also.

\section{Introduction}

Almost since the beginning of the system-economic transformation of the 90 s the influence of environmental regulations has been influencing the functioning of the economy and the investment process. This phenomenon has a number of reasons, including inter alia:

a) progressive contamination of the elements of the environment; 
b) spatial expansion of towns and different forms of business activity resulting in specific „hunger” for space especially in economically attractive locations (Drapella-Hermansdorfer, 2005, pp. 35-43; Opdam, Steingr"over, van Rooij, 2005, pp. 322-332);

c) increasing ecological awareness of the community (Chojecka 2014, pp. 48-54; Mierzejewska, 2015, pp. 9-22);

d) development of the system of spatial forms of nature protection (Dziemianowicz, Peszat, Przyborowski, 2015, pp. 86-103; Zuzek, 2017, pp. 169-178);

e) necessity to adjust the Polish legal system to the regulations of the European Union.

As a result of the processes a very complicated legal system was created, governing the principles of using the environment and assessing impact on the environment in the process of allocating, realizing and functioning of the investment. Focal legal acts are surrounded with numerous regulations which significantly affect everyday functioning of the enterprises. A large number of different obligations requiring specialist knowledge, often also specialist measuring and calculation tools, create favorable conditions for a gradually maturing market of specialist services in the scope of the environmental advisory. Numerus provisions which govern the environmental issues are addressed to the entities using the environment for economic purposes or which just barely intend to use the resources of the environment in connection with the activity planned.

\section{Legal conditions of the market of services in the scope of environmental advisory}

Legal norms in the area of the environment protection define the purposes and tasks and at the same time form the tools (means of realization) protecting the environment. The applicable provisions are shaped by 3 groups of economic entities in connection with the planned and/or realized usage of the resources of the environment:

- obtaining initial permit for the realization of the investment in the form of decisions on environmental conditions,

- obtaining permits and approvals entitling to use the environment and defining the conditions to use it in connection with planned business activity,

- documenting actual usage of the environment and the changes introduced therein.

A legal basis of the obligations of the first of these groups is the Act on making information available on the environment and its protection, participation of the community in the protection of the environment and on the assessments of the impact on the environment (Journal of Law of 2018 item 2081). The legislator established two documents presenting a characteristics of the planned undertaking defining the demand for the resources of the environment and forecasting the type and scale of potential impact on the environment in the phase of its realization, exploitation and liquidation:

- information card of the undertaking, constituting basic evidence material to issue the decision on environmental conditions,

- report on impact of the planned undertaking on the environment constituting a key evidence material in the assessment of the impact on the environment.

Both said documents are submitted to the body of the environment protection by the investor, whereas the report on impact of the undertaking on the environment may be prepared or advertised only by the author fulfilling requirements defined in the scope of education and experience. 
Obligations of the entrepreneurs concerning obtaining permits and approvals entitling to use the environment and defining the conditions of using it in connection with the planned business activity are dispersed in a few acts of act level:

- act of 21.4.2001 Environment law (i.e. Journal of Law of 2018 item 799 as amended), governing the mode of obtaining permits for introducing into the environment the substances or energy (like immision of the gases or generation of waste),

- act 20.7.2017 Water law (i.e. Journal of Law of 2018 item 2268 as amended) governing the issues of permit for performing water devices and granting water-legal consents,

- act of 14.12.2012 on waste (i.e. Journal of Law of 2018 item 992 as amended), governing broadly understood waste management.

Current functioning of the company in agreement with the provisions creating the law system of the environment shall require to prepare company catalogue of obligations defined in nearly 30 legal acts in the rating of the Act. These obligations cover first of all required measurements of the emission, preparing lists and registers, self-calculating fees and preparing reports on using the environment or conducting business activity which affects the environment.

\section{Economic entities connected with environmental advisory}

The companies providing advisory services in environment are characterised by significantly developed range of the services offered, which makes it difficult to respect their number. In Polish Classification of Economic Activity (PKD 2007) the mentioned activities are ascribed to many sectors and sections. The most often realized forms are placed in the section $\mathrm{M}$ (professional, scientific and technical activity):

- 71.11.Z - urban development and architectonic shaping the landscape,

- 71.20.B - performing tests, measurements and chemical and biological analyses of the composition and cleanliness of water and air,

- 72.19 - scientific research and developmental works,

- 74.90 - advisory in natural environment.

This section covers advisory activity, performance of the documentation connected with the investment process, project works in the scope of shaping landscape and measurements and analyses (including often the works performed involving registration of natural biodiversity - stock-taking, lists, identification tests).

In section $\mathrm{O}$ (Public administration and economic and social politics) one may distinguish one class of services:

- 84.13 - Managing in the scope of economics effectiveness,

covering the activity with the outsourcing nature in the scope of conducting environmental issues (documentation, reporting, monitoring, service of the investment) for the administration and commercial economic activities.

Last significant section PKD is the section $\mathrm{P}$ (education):

- 85.59.B - other non-school forms of education,

- 85.60 - activity supporting education.

The economic entities most often deal with preparing and conducting supplementary educational classes and specialist trainings within non-school education (mainly in the scope of the economic subjects in the environment protection). 


\section{Review of the services within environmental advisory \\ Services dedicated to the investment activities}

One of the main areas of operation of companies offering the environmental services is to support the investment process in the scope of the selection of the location and assessment of the impact on the environment. A wide scope of services shall require constant cooperation with the investor, designers and bodies of environment protection in order to develop one position, which will allow to obtain the consent. Most often it is also the first stage of long-term cooperation between entrepreneur and consulting company. A range of services (Table 1) is very broad.

Table 1. Services dedicated for the investment activities of the entrepreneurs

\begin{tabular}{cl}
\hline No. & \multicolumn{1}{c}{ Services offered } \\
\hline 1. & Developing applications for the funds for the development in agreement with the purposes of the environment protection \\
2. & Preparing information cards \\
3. & Preparing reports on impact of the planned undertakings \\
4. & Analyses of the impact of the planned undertakings on the environment (landscape, acoustic, emission analyses, climatic sensitivity) \\
5. & Environmental screening with an indication for the optimum location for the selected type of the undertaking \\
6. & Collecting samples, testing contents of the substances causing the risk and assessment of the pollution of soil and land against \\
7. & Assessment of the collision with an investment intention and planning natural compensation (i.a. consequent planting in.) \\
8. & Cooperation with designers, limiting the impact on the environment \\
9. & Performing post-realization analyses resulting from the decisions issued \\
10. & Representing the investor before the bodies environment protection \\
11. & Developing water-legal quantity surveys for the construction of water devices \\
12. & Conducting natural supervision in the phase of realization of the investment \\
\hline
\end{tabular}

Source: own elaboration.

\section{Services dedicated to preparing the company to stapt activity}

Another very important section of services in the scope of environmental advisory is the support for proper, legal commencement of activity. A complicated legal system of the natural environment makes that on the stage of commencing the functioning of the company, installation or the firm, the investor frequently uses the environmental advisory. Entrusting to the external company all environmental obligations connected with commencement of the activity releases the entrepreneur from the necessity to participate in complex administration procedures or complicated process of preparing detailed studies. Below (Table 2) the services of the market of environmental advisory which allows for the entrepreneur to start the activity properly.

Table 2. Services dedicated to prepare the company to start activity

\begin{tabular}{cl}
\hline No. & \multicolumn{1}{c}{ Offered services } \\
\hline 1. & Developing applications for issuing permits and approvals in the scope of environment protection \\
2. & Legal advisory in the scope of environmental requirements \\
3. & Preparing the entrepreneur and participation in the control of the company before giving the permit or the approval \\
\hline
\end{tabular}

Source: own elaboration. 


\section{Sepvices dedicated to conducted business activity}

Within the frames of the services offered in the category (Table 3 ) there is also performing current obligations of the company in connection with the use of the environment, review of the correctness of these obligations as well as cooperation with entrepreneurs in actions of control bodies of environment protection. Thus, one may call the sector of the activity (Carey, Subramaniam, Ching, 2006, pp. 118-141) environmental outsourcing causing transferring by the enterprise a part of its competences to the specialized external entities (Gilley, Rasheed, 2000, pp. 133-147). Cooperation with the experienced consulting team means optimising the costs in the area of the environment protection, fulfilling legal requirements, guarantee for the punctual fulfilling the obligations and many times also avoiding penalties (Smużniak, 2013, pp. 31-54).

Table 3. Dedicated services offered of the business activity

\begin{aligned} & \hline No. \multicolumn{1}{c}{ Offered services } \\ & \hline 1. Environmental audit in the company (monitoring of legal obligations) \\ & 2. Cooperation in performing decisions, ordinances and post-control recommendations \\ & 3. Representing the company before the bodies of environmental, self-government appeal boards and administration courts \\ & 4. Preparing information required by the provisions, lists and reports on activity in the scope adjusted to the specifics of the company \\ & 5. Reminding the changes in law \\ & 6. Conducting documentation and register of using the environment with introducing data into the defined bases and registers \\ & 7. Charging due amounts for using the environment, product, recycling, including advisory in optimisation of costs \\ & 8. Selection of cooperators providing services connected with environment protection \\ & 9. Implementing and monitoring the system of environment management \\ & 10. Creating specialist IT tools dedicated to realize the environment obligations \\ & 11. Collecting environment samples and performing required tests \\ & 12. Conducting trainings for the employees \end{aligned}

Source: own elaboration.

Usually complete environmental outsourcing is recommended to small and medium companies which have no separated section dealing with the environment protection. The external company takes over then partial or all obligations and liability resulting from the provisions of law in this respect.

\section{Analysis of the entities providing services of the environment advisory in Wester Pomerania region}

Quantity and quality analysis of economic entities dealing with the services of the environment advisory is difficult due to varied nature of the activity. The statistical information available in the Bank of Local Data (BDL) refers to sections and divisions while the sectors described above of operation of the companies providing services of environment advisory constitute a set of classes and sub-classes. As a result, the list presented below shows a wider topic scope of activity of the entities. In the analysis the quantity variety of the entities registered was presented registered in class $M 74$, in which a basic scope of activities is placed. As the section covers, besides the environment advisory, also other sections (i.a. photo services, translations and specialist design) one should presume that the actual number of the environment companies in the unit covers not more than $20-40 \%$ presented values. 
Per country, a number of the registered entities is very varied and fluctuates from about 2-3 thousands of entities (2017) in seven regions (Figure 1), by 5 regions in which it reaches the value of $6-8$ thousands, to above 17 thousands in the mazowieckie region The companies declaring the activity in the section achieve the largest population in the regions characterized by a high degree of business activity based on urban agglomerations (mazowieckie, dolnośląskie, małopolskie, wielkopolskie, śląskie).

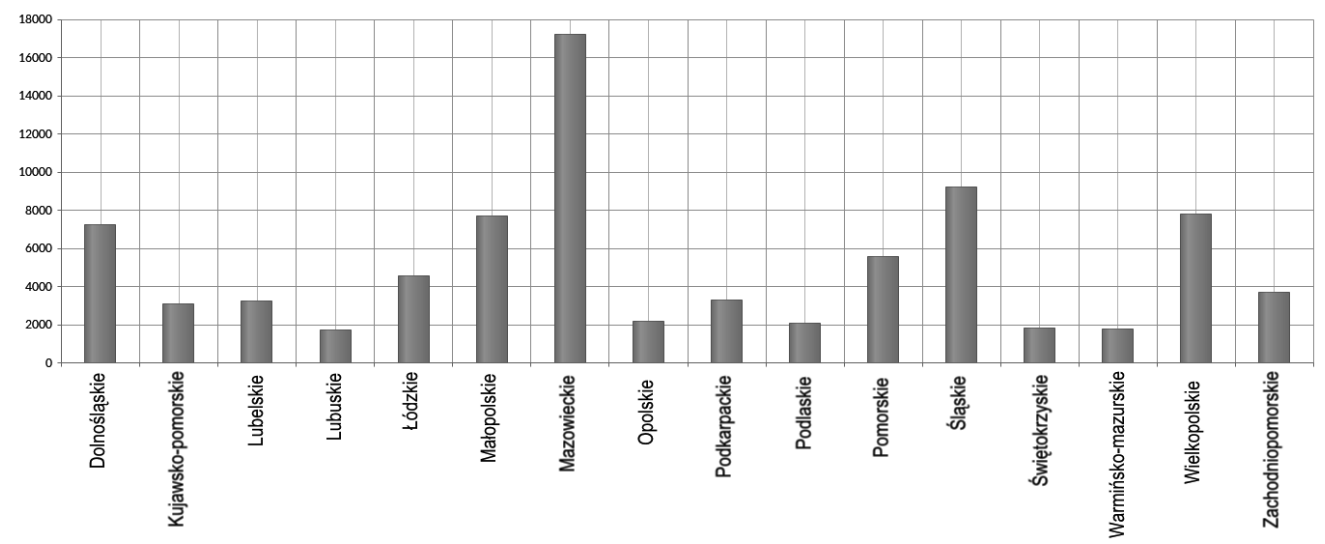

Figure 1. A number of economic entities of section M 74 in Polish regions (2017)

Source: own elaboration.

In the West Pomerania region, in 2017, there were 3,711 entities of the type were registered which gives 8th place in a domestic list. Out of this number, there are 3,381 natural persons conducting business activity, 328 companies and 2 cooperatives. A majority of the companies are the enterprise of private domestic capital. Barely one company of state treasury and self-territorial government each was observed and 48 with a share of the foreign capital. A majority of the entities registered are the small ones, one-person frequently - barely 21 of them employ more than 10 persons. The competition and difficulty in functioning on the market of such enterprises are proved by the fact that within a year (2016-2017) with a minimum change of the population of the registered companies (drop by 1 ) as many as 1,045 deregistered in the period their activity.

A spatial location of the entities is confirmed by a strong connection with the level of the economic development of the region. Its specifics is characterised also by a large natural value of the area of the region. The high percent of the area covered with different area forms of the natural protection, directs the development of the region towards more sustained management of the area and creates a number of limitations in the investment process. These advantages however extend the market of advisory services.

Spatial location of the enterprises presented in the region points for their relations with large municipal centers (Figure 2). The entities registered in the municipal poviates of Szczecin $(1,539)$ and Koszalin (404) have an overwhelming dominant position. The affiliation with large cities, in which the investments are concentrated and large enterprises being the clients of the sector is proved by the quite high number of enterprises in the 
Police (252), stargardzki (185) and kołobrzeski (160) poviates. In the remaining poviates, a number of entities does not exceed 100 .

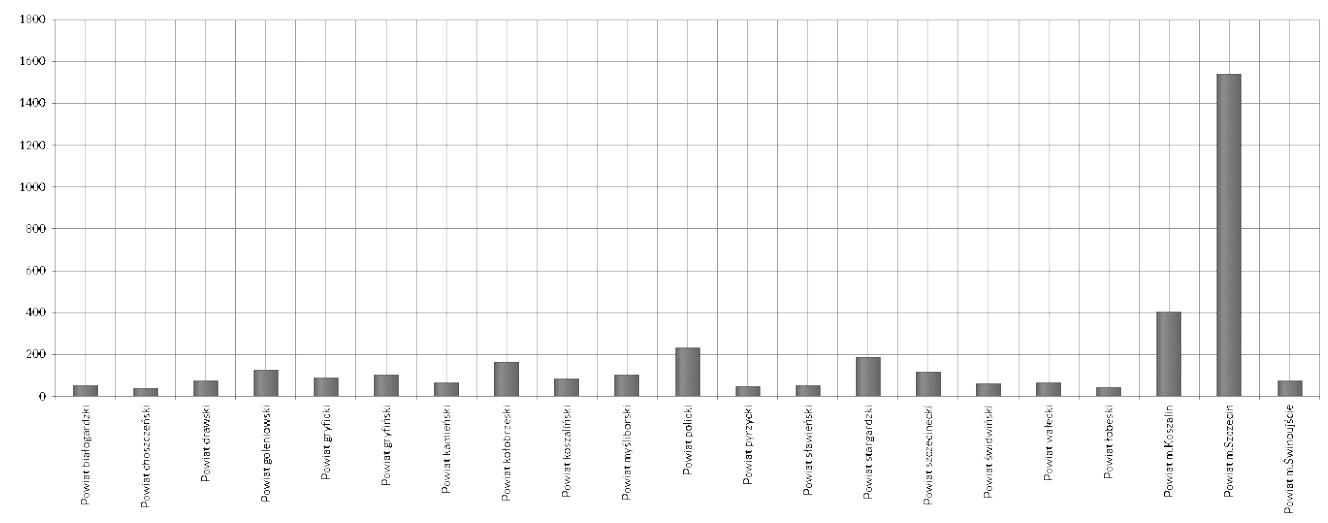

Figure 2. A number of economic entities of section M 74 in zachodniopomorski region (2017)

Source: own elaboration.

\section{Conclusions}

Specifics of the presented sector of services included a broad scope of activity. It forces frequently the cooperation of the small, often one-person companies providing them. Broad and multi-aspect tasks force creating consortia or employment of a number of specialist subcontractors. Most often these are persons connected with the academic sector. The entities providing the environment services declare activity in the area of the whole country but due to a significant share of field activities a majority of them is of local nature, where the limitation of the area of operation are the costs of trips and activity in the distant locations.

A requirement for certification of results makes the companies disposing of a proper equipment and measurement background facilities. Therefore, usually they use services of certified laboratories limiting to the collection of attempts. The exception here are the stock-taking works in such areas as dendrology, ornithology, florist and eco-physiographic tests.

One should presume that due to the tendency of constant changes and in the legal system which is anyway very complicated, the environment protection and growing threats connected with its excessive exploitation (adaptation to climatic changes, transformation of power engineering, spatial conflicts), market of advisory services in environment protection will develop further on. However, the quantity and quality structure of the enterprise will be subject to dynamic transformations with an increase of competitiveness of enterprise and development of their specialization. 


\section{References}

Carey, P., Subramaniam, N., Ching, K.C.W. (2006). Internal audit outsourcing in Australia. Accounting and Finance, 46, $118-141$.

Chojecka, A. (2014). Znaczenie terenów zielonych w przestrzeni publicznej oraz ich wpływ na jakość życia miejskiego. Rynek Społeczeństwo - Kultura, 1 (9), 48-54.

Drapella-Hermansdorfer, A. (2005). Zieleń-woda-recykling przestrzeni. Wybrane aspekty przyrodniczej rewitalizacji miast. Teka Komisji Architektury, Urbanistyki i Studiów Krajobrazowych, I, 35-43.

Dziemianowicz, W., Peszat, K., Przyborowski, K. (2015). Natura 2000 w kontekście konkurencyjności i możliwości rozwojowych gmin w Polsce. Studia Regionalne i Lokalne, 1 (59), 86-103.

Gilley, K.M., Rasheed, A. (2000). Making more by doing less: an analysis of Outsourcing and its Effects on Firm Performance. Journal of Management, 26 (4). 133-147.

Mierzejewska, L. (2015). Miasto zwarte, rozproszone, zrównoważone. Studia Miejskie, 19, 9-22.

Opdam, P., Steingr"over, E., van Rooij, S. (2005). Ecological networks: A spatial concept for multi-actor planning of sustainable landscapes. Landscape and Urban Planning, 75, 322-332.

Smużniak, M. (2013). Outsourcing w e-biznesie. In: Biblia e-biznesu. Gliwice: Helion.

Zuzek, D.K. (2017). Obszary chronione Natura 2000 a lokalna przedsiębiorczość w województwie małopolskim. Zeszyty Naukowe Politechniki Śląskiej, 12, 169-178.

Cite this article aS: Dusza-Zwolińska, E., Kupiec, M., Kiepas-Kokot, A. (2018). Specification of Environmental Consulting Services in Poland and Western Pomerania. European Journal of Service Management, 4 (28/2), 141-148. DOI: 10.18276/ejsm.2018.28/2-17. 